\title{
The Effect of Systematic Risk and Previous Period Returns on Portfolio Selection
}

\author{
Cem Berk ${ }^{1}, \&$ Bekir Tutarli ${ }^{2}$ \\ ${ }^{1}$ Kirklareli University, Turkey \\ ${ }^{2}$ Independent Researcher, Turkey \\ Correspondence: Cem Berk, Kirklareli University, Turkey.
}

Received: September 14, 2020

doi:10.11114/afa.v7i1.5051
Accepted: October 5, 2020

Available online: October 22, 2020

URL: https://doi.org/10.11114/afa.v7i1.5051

\begin{abstract}
There are many techniques to determine investable set of portfolios given return data of assets. However, the theoretical results do not always point out the best portfolios in practice. This is due to the fact that financial dynamics are so difficult to be modelled and this requires many assumptions. The investor may have some preferences to select portfolios. In this study, two selection criteria are proposed to be applied in a mean variance optimization. These criteria are beta coefficient which is a measure of systematic risk and previous period return.

The study has an empirical analysis applied on Istanbul Stock Exchange. The findings of the study confirm that these selection criteria may be used to obtain investable portfolios. The analysis with beta selection criteria reveal that the portfolio with lowest 5 beta coefficients is the best alternative. This means that the advantage of low beta which is a natural hedge when stock values declineis superior to diversification benefits of adding new stocks.

The previous period return analysis suggest two alternative portfolios. In addition, one of these portfolios generate higher return than the portfolio selected with beta selection criterion. This is also a higher risk portfolio. Therefore the decision is based on risk profile of the investor.

This research offer to add selection criteria to the standard approach which is beneficial for academic and practical purposes in portfolio management.
\end{abstract}

Keywords: beta selection criteria, mean variance optimization, previous period return, portfolio theory, systematic risk

JEL Classification: D81, G11, G321.

\section{Introduction}

A stock risk is composed of systematic and unsystematic components. Systematic risk is all the risks that is available for all stocks for portfolio such as interest rate risk and inflation. Unsystematic risk (or as often called idiosyncratic risk) is the risk associated with a single stock such as management performance, leverage, or operational risks.

These risks together with return data is used to construct portfolios in portfolio management practice. Since Markowitz (1952)- who developed what is known today as Modern Portfolio Theory(MPT), investors try to minimize unsystematic risk of a portfolio. He showed mathematically that unsystematic risk isn't just sum of that of all stocks in the portfolio but also a covariance matrix plays a role. In other words, the lower the covariance between stocks, the lower the portfolio risk.

Modern portfolio theory is also applied in this research. The motivation of this paper is to see if it is possible to construct portfolios based on beta (a measure of systematic risk) and previous period returns of stocks. If this is possible, then stocks that generate the best portfolios based on systematic risk and previous period return can be determined.

By adding stocks to a portfolio, diversification is obtained. That is a risk reduction in the portfolio. However, this is limited to the systematic risk, beyond which the variance of the portfolio cannot be further reduced. Systematic risk is measured by the beta coefficient. According to Sharpe (1988), beta coefficient measures the sensitivity of individual stock return to the market return. Beta can be computed with any of the following formulas. 


$$
\beta_{i}=\frac{\operatorname{Cov}_{i, M}}{\sigma_{M}^{2}} \quad \text { or } \quad \beta_{i}=\frac{\sigma_{i}}{\sigma_{M}} * r_{i, M}
$$

$\beta_{i}$ : The beta coefficient of stock $\mathrm{i}$,

$\operatorname{Cov}_{i, M}$ : Covariance between stock i and market portfolio,

$\sigma_{M}^{2}$ : The variance of market portfolio,

$\sigma_{i}:$ Standard deviation of stock i,

$\sigma_{M}:$ Standard deviation of market portfolio,

$r_{i, M}$ : Correlation coefficient between stock i and market portfolio.

By constructing a portfolio, the goal is to forecast portfolio and individual stock returns with a probability distribution. Based on Markowitz(1952) stock returns are assumed to be normally distributed. These applications are crucial for academica and practical purposes. As Chen (2000) said, forecasting is crucial for the management of the company, capital markets, stockholders and investors.

Mean variance optimization(MVO) as shown in Markowitz(1952) isn't the only technique to obtain the variance from individual stock return as explained in the methodology section. Linsmeier and Pierson (1996) explain that one can use historical simulation based on previous period returns and volatilities. A probability distribution can then be obtained for the portfolio return from which we can attain and use as a risk measure; the value at risk. (VaR)

Another aspect of the portfolio theory is stock returns. To see if the portfolio can be constructed with previous return criterion, individual stock returns are obtained in the study. The mean of a stock is just the arithmetic average for the previous period returns. Abnormal return is calculated as the period return less the mean. The previous period return of an individual stock can be measured with the following formula.

$$
R_{i}=\frac{P_{t}-P_{t-1}}{P_{t-1}}
$$

$R_{i}$ : Rate of return of stock $\mathrm{i}$,

$P_{t}$ : Price of stock $i$ at the end of the period,

$P_{t-1}$ : Price of stock i at the end of the previous period,

The research is important becasuse it offers a new technique in MPT applications. The beta and previous period return based expectations of the investors can be included in portfolio management practice. The standard approach requires normality assumption which can not often be maintained in financial markets. This way, the investors may decide and limit the portfolio based on their risk profile.

The rest of the study is organized as follows. The next section covers some notable previous studies related to this research. Main focus of the study section consists of scope and the methodology applied in this research. In the solutions and recommendations section, results for both beta and previous return criteria and investment decision is available. In the discussion section, the findings of the study are elaborated. The conclusion section includes the final thoughts regarding this study.

\section{Background}

One of the interesting aspects of MPT is that it has a variety of uses. It can be applied with various different aseets and institutions. It is not the tool of asset management companies only.

Lord(2020) studied university endowments and decision making process. The results of the study show that the use of MPT generate diversified portfolios. These portfolios have higher risk adjusted returns. The portfolios with more asset classes also lead to more diversified portfolios.

Modern portfolio theory(MPT) is a rather old theory. There are some criticisms on how well the theory can be applied in todays' financial markets.

Fischer(2019) studied MPT and efficient market hypothesis (EMH) in Canada. The research period is between 1997 and 2016. The results of the study reveal that the savings generated by a portfolio created with MPT is enough retirement income for a modern family.

MPT is applied in many different countries. The stable results obtained in different markets show that the theory is sound. 
Abu Bakar (2019) made an analysis on Kuala Lumpur Stock Exchange. Efficient frontier is calculated in this study. Possible portfolio returns and variances are obtained. The stocks in the portfolio have negative Pearson correlation which is good for diversification benefits. Due to assumptions of the theory, normality is also tested.

There are many studies on Modern Portfolio Theory. (MPT) This study includes an empirical research on Istanbul Stock Exchange. (ISE)

In MPT, the goal is to find optimal portfolios based on risk and return criteria. There are more than one investable portfolio in efficient frontier. Therefore, the investor can make the final choice depending on his/her risk preference.

Atan (2005) applied Mean Variance Optimization (MVO) on ISE. The research period is between 2003 and 2004. In this study, Atan found some portfolios with low level of risk given a specified level of return. Different portfolios are then suggested for different risk profiles of the investor.

There are alternative ways to measure the mean and variance while applying MPT. One of the assumptions of Markowitz (1952) is normal distribution. Today, alternative techniques have been developed which don't require normal distribution.

Kocadagli and Cinemre (2010) applied fuzzy non-linear model in portfolio optimization. The technique is based on Capital Asset Pricing Model. (CAPM) They used BIST 30 (bluchip index for 30 stocks in ISE) stocks in the research. The research period is 2008 . They found expected return, level of risk, portfolio beta and finally optimal portfolio.

Once the portfolio is formed, it is important to track its performance. There are alternative approaches to do this. Sharpe, Treynor and Jensen performance indicators are used most frequently in this field.

Caliskan(2011) used MVO and Black- Litterman models to construct portfolios. They had 17 stocks from BIST 30(ISE 30) index to form 13 portfolios. The research period is between 2003 and 2009. They then measured the portfolio performance with Sharpe, Treynor and Jensen. They found that portfolios selected with Black Litterman model performed better.

One of the choices during the analysis is the time interval to be used for return series. One can analyze with several alternatives such as daily, quarterly, and annual. The findings might be different based on the time interval used.

Aygoren and Akyer (2013) analyzed time interval, number of stocks, and level of risk factors in their study. They selected stocks within BIST 30 (ISE 30) index. The research period is between 1994 and 2011. They found that daily and weekly analysis are superior in their analysis.

Mean variance optimization is again not the only method to construct portfolios. A more stochastic approach is log optimal portfolio.

Ustaoglu and Altay (2017) studied log optimal portfolio in BIST 100(ISE 100) index. They analyzed 59 stocks. The research period is between 2000 and 2015. They found that, in 29 analysis out of $32 \log$ optimal approach is superior to the MVO.

\section{Main Focus of the Study}

\subsection{Presentation of the Scope of the Research}

In this study, 27 stocks which are listed in BIST 30 index are used. This is an empirical analysis of Modern Portfolio Theory. Mean Variance Optimization method is used in this study. The research period is the year 2018. Daily closing prices are used in the analysis.

BIST30 is the bluchip index of Istanbul Stock Exchange. The stocks in this index has high trading volume which is required for the soundness of the study. There are 30 stocks in this index. 3 stocks were traded less than 250 days in 2018. Therefore these stocks were excluded from the research.

During the study, several portfolios are formed based on two different criteria. The criteria used in the research is stock beta (systematic risk) and previous period return. The results are given in two different sections.

The motivation of the study is to see whether efficient portfolios can be obtained by using beta and previous period return criteria. If this could be obtained, a further analysis that can be made is which portfolios are superior within these criteria.

\subsection{Methodology}

The portfolios are constructed based on mean variance optimization (MVO). This means that return is measured by the mean of that individual stock and risk is measured by variance. As suggested by Markowitz (1952), the return of the portfolio can be obtained by the following formula. 
$E\left(R_{p}\right)=\mu_{p}$ : Expected Return of the Portfolio,

$$
E\left(R_{p}\right)=\mu_{p}=w_{1} \mu_{1}+w_{2} \mu_{2} \ldots . w_{N} \mu_{N}
$$

$\mu_{i}$ : Expected Return on stock i.

Risk is measured by the variance of the portfolio. Once again, the variance isn't just the sum of individual variances of stocks in the portfolio but covariances are of extreme importance. One has to analyze the covariances between every two assets available in the portfolio. Therefore the following computation had to be used in this study.

$$
\begin{gathered}
\sigma_{p}^{2}=w_{1}^{2} \sigma_{1}^{2}+w_{2}^{2} \sigma_{2}^{2}+w_{3}^{2} \sigma_{3}^{2}+\cdots+w_{N}^{2} \sigma_{N}^{2}+2 w_{1} w_{2} \operatorname{Cov}\left(r_{1}, r_{2}\right)+2 w_{1} w_{3} \operatorname{Cov}\left(r_{1}, r_{3}\right)+2 w_{2} w_{3} \operatorname{Cov}\left(r_{2}, r_{3}\right)+\cdots \\
+2 w_{N-1} w_{N} \operatorname{Cov}\left(r_{N-1}, r_{N}\right)
\end{gathered}
$$

$\sigma_{p}^{2}$ : The variance of the portfolio

$\operatorname{Cov}\left(r_{i}, r_{j}\right)$ : Covariance between stocks i and $\mathrm{j}$.

$w_{i}$ : Weight of the stock $i$ in the portfolio,

$w_{j}$ : Weight of the stock $\mathrm{j}$ in the portfolio,

$N$ :Number of securities in the portfolio

\section{Solutions and Recommendations}

\subsection{Beta Based Portfolio Analysis}

The first approach to determine the portfolios used in the study is to select them with their betas. As discussed in the introduction section of this study, beta coefficients are computed by dividing covariance of the stock and the market (BIST - ISE 30 index) to the variance of the market. The results are given in Table 1.

Table 1. Beta Ratios for the Companies

\begin{tabular}{|l|l|l|}
\hline TICKER & COMPANY & COEFFICIENT \\
\hline GARAN & GARANTI BANKASI & 1.4208 \\
\hline THYAO & TURK HAVA YOLLARI & 1.3443 \\
\hline AKBNK & AKBANK & 1.3013 \\
\hline PGSUS & PEGASUS & 1.2816 \\
\hline HALKB & T. HALK BANKASI & 1.2782 \\
\hline VAKBN & VAKIFLAR BANKASI & 1.2748 \\
\hline KRDMD & KARDEMIR (D) & 1.2494 \\
\hline YKBNK & YAPI VE KREDI BANK. & 1.2262 \\
\hline ISCTR & IS BANKASI (C) & 1.1613 \\
\hline KOZAA & KOZA MADENCILIK & 1.0986 \\
\hline KOZAL & KOZA ALTIN & 1.0375 \\
\hline PETKM & PETKIM & 0.9624 \\
\hline EREGL & EREGLI DEMIR CELIK & 0.9333 \\
\hline SAHOL & SABANCI HOLDING & 0.8400 \\
\hline TCELL & TURKCELL & 0.8342 \\
\hline TTKOM & TURK TELEKOM & 0.8294 \\
\hline ASELS & ASELSAN & 0.7272 \\
\hline SISE & SISE CAM & 0.6910 \\
\hline KCHOL & KOC HOLDING & 0.6867 \\
\hline ARCLK & ARCELIK & 0.6858 \\
\hline EKGYO & EMLAK KONUT GMYO & 0.6804 \\
\hline DOHOL & DOGAN HOLDING & 0.6313 \\
\hline TOASO & TOFAS OTO. FAB. & 0.5925 \\
\hline TAVHL & TAV HAVALIMANLARI & 0.5083 \\
\hline TUPRS & TUPRAS & 0.5035 \\
\hline TKFEN & TEKFEN HOLDING & 0.4174 \\
\hline BIMAS & BIM MAGAZALAR & 0.3249 \\
\hline & & \\
\hline & & \\
\hline
\end{tabular}

It is known from literature that beta ratios more than one indicate aggressive stocks, whereas those of less than one indicate conservative stocks. Aggressive means stocks move faster relative to market, conservative means stocks move slower. Using 1 which is the beta value for the market as the reference number, four categories of portfolios are 
determined. The categories are five largest beta, five lowest beta, stocks with beta more than one, and stocks with beta less than one. Stocks in these categories are given in Table 2.

Table 2. Portfolios Selected with Beta Criteria

\begin{tabular}{|c|c|c|c|}
\hline PORTFOLIO & TICKER & COMPANY & BETA COEFFICIENT \\
\hline \multirow{5}{*}{$\begin{array}{l}\text { PORTFOLIO } 1 \\
\text { (largest five beta) }\end{array}$} & GARAN & GARANTI BANKASI & 1.4208 \\
\hline & THYAO & $\begin{array}{ll}\text { TURK } & \text { HAVA } \\
\text { YOLLARI }\end{array}$ & 1.3443 \\
\hline & AKBNK & AKBANK & 1.3013 \\
\hline & PGSUS & PEGASUS & 1.2816 \\
\hline & HALKB & T. HALK BANKASI & 1.2782 \\
\hline \multirow{5}{*}{$\begin{array}{l}\text { PORTFOLIO } 2 \\
\text { (lowest five beta) }\end{array}$} & TOASO & TOFAS OTO. FAB. & 0.5925 \\
\hline & TAVHL & $\begin{array}{l}\text { TAV } \\
\text { HAVALIMANLARI }\end{array}$ & 0.5083 \\
\hline & TUPRS & TUPRAS & 0.5035 \\
\hline & TKFEN & TEKFEN HOLDING & 0.4174 \\
\hline & BIMAS & BIM MAGAZALAR & 0.3249 \\
\hline \multirow{11}{*}{$\begin{array}{l}\text { PORTFOLIO } 3 \\
\text { (Betas more than one) }\end{array}$} & GARAN & GARANTI BANKASI & 1.4208 \\
\hline & THYAO & $\begin{array}{ll}\text { TURK } & \text { HAVA } \\
\text { YOLLARI } & \\
\end{array}$ & 1.3443 \\
\hline & AKBNK & AKBANK & 1.3013 \\
\hline & PGSUS & PEGASUS & 1.2816 \\
\hline & HALKB & T. HALK BANKASI & 1.2782 \\
\hline & VAKBN & VAKIFLAR BANKASI & 1.2748 \\
\hline & KRDMD & KARDEMIR (D) & 1.2494 \\
\hline & YKBNK & $\begin{array}{lll}\text { YAPI } & \text { VE } & \text { KREDI } \\
\text { BANK. } & & \\
\end{array}$ & 1.2262 \\
\hline & ISCTR & IS BANKASI (C) & 1.1613 \\
\hline & KOZAA & KOZA MADENCILIK & 1.0986 \\
\hline & KOZAL & KOZA ALTIN & 1.0375 \\
\hline \multirow{16}{*}{$\begin{array}{l}\text { PORTFOLIO } 4 \\
\text { (Betas less than one) }\end{array}$} & PETKM & PETKIM & 0.9624 \\
\hline & EREGL & $\begin{array}{ll}\text { EREGLI } & \text { DEMIR } \\
\text { CELIK } & \end{array}$ & 0.9333 \\
\hline & SAHOL & SABANCI HOLDING & 0.8400 \\
\hline & TCELL & TURKCELL & 0.8342 \\
\hline & TTKOM & TURK TELEKOM & 0.8294 \\
\hline & ASELS & ASELSAN & 0.7272 \\
\hline & SISE & SISE CAM & 0.6910 \\
\hline & KCHOL & KOC HOLDING & 0.6867 \\
\hline & ARCLK & ARCELIK & 0.6858 \\
\hline & EKGYO & $\begin{array}{ll}\text { EMLAK } & \text { KONUT } \\
\text { GMYO } & \\
\end{array}$ & 0.6804 \\
\hline & DOHOL & DOGAN HOLDING & 0.6313 \\
\hline & TOASO & TOFAS OTO. FAB. & 0.5925 \\
\hline & TAVHL & $\begin{array}{l}\text { TAV } \\
\text { HAVALIMANLARI }\end{array}$ & 0.5083 \\
\hline & TUPRS & TUPRAS & 0.5035 \\
\hline & TKFEN & TEKFEN HOLDING & 0.4174 \\
\hline & BIMAS & BIM MAGAZALAR & 0.3249 \\
\hline
\end{tabular}

As explained in the methodology section of this study, it is possible to compute expected return and variance of the portfolio, given the return series of the stocks in the portfolio. The results are presented in Table 3.

Table 3. Expected Return and Variance of the Portfolios Based on Beta

\begin{tabular}{|l|l|l|l|}
\hline PORTFOLIO & $\begin{array}{l}\text { EXPECTED RETURN } \\
(\%)\end{array}$ & $\begin{array}{l}\text { VARIANCE } \\
(\%)\end{array}$ & $\begin{array}{l}\text { STD DEVIATION } \\
(\%)\end{array}$ \\
\hline PORTFOLIO 1 & -0.0693 & 0.0546 & 2.3368 \\
\hline PORTFOLIO 2 & 0.0213 & 0.0175 & 1.3213 \\
\hline PORTFOLIO 3 & -0.0743 & 0.0479 & 2.1895 \\
\hline PORTFOLIO 4 & -0.0404 & 0.0145 & 1.2045 \\
\hline
\end{tabular}




\subsection{Previous Period Return Based Portfolios}

Other criterion used in this study is previous returns for the stocks. Once again, the research period is 2018 . Therefore closing prices of stocks for the period 2017 are used in the previous return analysis. Average returns of the stocks for the year 2017 are given in Table 4.

Table 4. Previous Period Returns for the Companies

\begin{tabular}{|c|c|c|}
\hline TICKER & COMPANY & PREVIOUS PERIOD RETURN \\
\hline TUPRS & TUPRAS & 4.0415 \\
\hline THYAO & TURK HAVA YOLLARI & 0.4761 \\
\hline KRDMD & KARDEMIR (D) & 0.4414 \\
\hline TKFEN & TEKFEN HOLDING & 0.4209 \\
\hline KOZAL & KOZA ALTIN & 0.3862 \\
\hline ASELS & ASELSAN & 0.3758 \\
\hline PETKM & PETKIM & 0.3388 \\
\hline EREGL & EREGLI DEMIR CELIK & 0.3094 \\
\hline TCELL & TURKCELL & 0.2344 \\
\hline TAVHL & TAV HAVALIMANLARI & 0.2200 \\
\hline BIMAS & BIM MAGAZALAR & 0.2021 \\
\hline VAKBN & VAKIFLAR BANKASI & 0.1969 \\
\hline GARAN & GARANTI BANKASI & 0.1611 \\
\hline ISCTR & IS BANKASI (C) & 0.1462 \\
\hline SISE & SISE CAM & 0.1375 \\
\hline TOASO & TOFAS OTO. FAB. & 0.1350 \\
\hline KCHOL & KOC HOLDING & 0.1341 \\
\hline AKBNK & AKBANK & 0.1143 \\
\hline YKBNK & YAPI VE KREDI BANK. & 0.1085 \\
\hline SAHOL & SABANCI HOLDING & 0.0939 \\
\hline HALKB & T. HALK BANKASI & 0.0913 \\
\hline TTKOM & TURK TELEKOM & 0.0902 \\
\hline DOHOL & DOGAN HOLDING & 0.0842 \\
\hline ARCLK & ARCELIK & 0.0292 \\
\hline EKGYO & EMLAK KONUT GMYO & -0.0130 \\
\hline TUPRS & TUPRAS & 4.0415 \\
\hline THYAO & TURK HAVA YOLLARI & 0.4761 \\
\hline KRDMD & KARDEMIR (D) & 0.4414 \\
\hline TKFEN & TEKFEN HOLDING & 0.4209 \\
\hline KOZAL & KOZA ALTIN & 0.3862 \\
\hline ASELS & ASELSAN & 0.3758 \\
\hline PETKM & PETKIM & 0.3388 \\
\hline EREGL & EREGLI DEMIR CELIK & 0.3094 \\
\hline TCELL & TURKCELL & 0.2344 \\
\hline TAVHL & TAV HAVALIMANLARI & 0.2200 \\
\hline BIMAS & BIM MAGAZALAR & 0.2021 \\
\hline VAKBN & VAKIFLAR BANKASI & 0.1969 \\
\hline GARAN & GARANTI BANKASI & 0.1611 \\
\hline ISCTR & IS BANKASI (C) & 0.1462 \\
\hline SISE & SISE CAM & 0.1375 \\
\hline TOASO & TOFAS OTO. FAB. & 0.1350 \\
\hline KCHOL & KOC HOLDING & 0.1341 \\
\hline AKBNK & AKBANK & 0.1143 \\
\hline YKBNK & YAPI VE KREDI BANK. & 0.1085 \\
\hline SAHOL & SABANCI HOLDING & 0.0939 \\
\hline HALKB & T. HALK BANKASI & 0.0913 \\
\hline TTKOM & TURK TELEKOM & 0.0902 \\
\hline DOHOL & DOGAN HOLDING & 0.0842 \\
\hline ARCLK & ARCELIK & 0.0292 \\
\hline EKGYO & EMLAK KONUT GMYO & -0.0130 \\
\hline
\end{tabular}

In this analysis, previous period return is used as selection criteria. The categories are highest previous period returns, lowest previous period returns, previous period returns more than $0,2 \%$, and previous period returns less than $0,2 \%$. The portfolios constructed with this criteria are shown in Table 5. 
Table 5. Portfolios Based on Previous Period Return Criteria

\begin{tabular}{|c|c|c|c|}
\hline PORTFOLIO & TICKER & COMPANY & $\begin{array}{ll}\text { PREVIOUS } & \text { PERIOD } \\
\text { RETURN } & \\
\end{array}$ \\
\hline \multirow{5}{*}{ 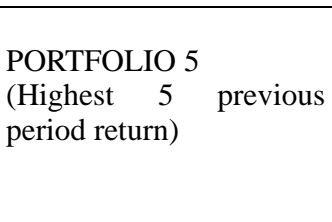 } & TUPRS.E & TUPRAS & 4.0415 \\
\hline & THYAO.E & $\begin{array}{ll}\text { TURK } & \text { HAVA } \\
\text { YOLLARI } & \end{array}$ & 0.4761 \\
\hline & KRDMD.E & KARDEMIR (D) & 0.4414 \\
\hline & TKFEN.E & TEKFEN HOLDING & 0.4209 \\
\hline & KOZAL.E & KOZA ALTIN & 0.3862 \\
\hline \multirow{5}{*}{$\begin{array}{ll}\text { PORTFOLIO } 6 & \\
\text { (Lowest } 5 & \text { previous } \\
\text { period return) } & \end{array}$} & HALKB.E & T. HALK BANKASI & 0.0913 \\
\hline & TTKOM.E & TURK TELEKOM & 0.0902 \\
\hline & DOHOL.E & DOGAN HOLDING & 0.0842 \\
\hline & ARCLK.E & ARCELIK & 0.0292 \\
\hline & EKGYO.E & $\begin{array}{ll}\text { EMLAK } & \text { KONUT } \\
\text { GMYO } & \\
\end{array}$ & -0.0130 \\
\hline \multirow{11}{*}{$\begin{array}{l}\text { PORTFOLIO } 7 \\
\text { (Previous period returns } \\
\text { more than } 0,2 \% \text { ) }\end{array}$} & TUPRS.E & TUPRAS & 4.0415 \\
\hline & THYAO.E & $\begin{array}{ll}\text { TURK } & \text { HAVA } \\
\text { YOLLARI } & \\
\end{array}$ & 0.4761 \\
\hline & KRDMD.E & KARDEMIR (D) & 0.4414 \\
\hline & TKFEN.E & TEKFEN HOLDING & 0.4209 \\
\hline & KOZAL.E & KOZA ALTIN & 0.3862 \\
\hline & ASELS.E & ASELSAN & 0.3758 \\
\hline & PETKM.E & PETKIM & 0.3388 \\
\hline & EREGL.E & $\begin{array}{l}\text { EREGLI DEMIR } \\
\text { CELIK }\end{array}$ & 0.3094 \\
\hline & TCELL.E & TURKCELL & 0.2344 \\
\hline & TAVHL.E & $\begin{array}{l}\text { TAV } \\
\text { HAVALIMANLARI }\end{array}$ & 0.2200 \\
\hline & BIMAS.E & BIM MAGAZALAR & 0.2021 \\
\hline \multirow{14}{*}{$\begin{array}{l}\text { PORTFOLIO } 8 \\
\text { (Previous period returns } \\
\text { less than } 0,2 \% \text { ) }\end{array}$} & VAKBN.E & VAKIFLAR BANKASI & 0.1969 \\
\hline & GARAN.E & GARANTI BANKASI & 0.1611 \\
\hline & ISCTR.E & IS BANKASI (C) & 0.1462 \\
\hline & SISE.E & SISE CAM & 0.1375 \\
\hline & TOASO.E & TOFAS OTO. FAB. & 0.1350 \\
\hline & KCHOL.E & KOC HOLDING & 0.1341 \\
\hline & AKBNK.E & AKBANK & 0.1143 \\
\hline & YKBNK.E & $\begin{array}{lll}\text { YAPI } & \text { VE } & \text { KREDI } \\
\text { BANK. } & & \\
\end{array}$ & 0.1085 \\
\hline & SAHOL.E & SABANCI HOLDING & 0.0939 \\
\hline & HALKB.E & T. HALK BANKASI & 0.0913 \\
\hline & TTKOM.E & TURK TELEKOM & 0.0902 \\
\hline & DOHOL.E & DOGAN HOLDING & 0.0842 \\
\hline & ARCLK.E & ARCELIK & 0.0292 \\
\hline & EKGYO.E & $\begin{array}{ll}\text { EMLAK } & \text { KONUT } \\
\text { GMYO } & \end{array}$ & -0.0130 \\
\hline
\end{tabular}

Similar to the analysis with beta criteria, the expected return and variance values for the above portfolios are calculated with mean variance optimization methodology. The results of the analysis are available in Table 6.

Table 6. Expected Return and Variance Values of the Portfolios Based on Previous Period Return

\begin{tabular}{|l|l|l|l|}
\hline PORTFOLIO & $\begin{array}{l}\text { PORTFOLIO } \\
\text { EXPECTED } \\
\text { RETURN }(\%)\end{array}$ & $\begin{array}{l}\text { PORTFOLIO } \\
\text { VARIANCE } \\
(\%)\end{array}$ & $\begin{array}{l}\text { PORTFOLIO STD. } \\
\text { DEVIATION } \\
(\%)\end{array}$ \\
\hline PORTFOLIO 5 & 0.0603 & 0.0321 & 1.7905 \\
\hline PORTFOLIO 6 & -0.0917 & 0.0327 & 1.8085 \\
\hline PORTFOLIO 7 & 0.0096 & 0.0208 & 1.4437 \\
\hline PORTFOLIO 8 & -0.1116 & 0.0288 & 1.6979 \\
\hline
\end{tabular}




\subsection{Investment Decision}

Based on the results with beta selection criteria, only portfolio $2(0.0213)$ generates positive return. Portfolios 1,3 and 4 has negative (Portfolio 1: -0.0693, Portfolio 3: -0.0743, Portfolio 4: -0.0404) returns. Despite negative returns Portfolios 1 and 3 have higher level of risk than portfolio 2. Portfolio 2 is therefore an investable portfolio based on beta selection criteria.

In the other analysis with previous period return selection criteria, Portfolios 5 and 7 generate positive return (Portfolio 5: 0.0603, Portfolio 7: 0.0096), whereas Portfolios 6 and 8 has negative returns. (Portfolio 6: -0.0917, Portfolio 8: -0.1116) Portfolio 6 has highest level of risk despite the negative return. Portfolio 7 has both higher return and higher level of risk when compared with Portfolio 5. Therefore investors may select both portfolios based on their risk preference.

\section{Discussion}

This study includes a Mean Variance Optimization (MVO) analysis. The analysis has two parts; one is with systematic analysis (beta) selection criterion and the other is previous return selection criterion.

Portfolio 2 is suggested in the investment selection part of this study based on beta selection criteria. Portfolio 2 consist of 5 stocks with lowest beta values. Portfolio theory is based on the concept of diversification. When the number of securities with low correlation increase, the portfolio variance decreases. However, in this application 14 stock portfolio- Portfolio 4 has negative return. Therefore, the advantage of holding low beta stocks outweigh diversification benefits. Low beta stocks are natural hedge especially when there is a decrease in market prices.

Portfolios 5 and 7 are investable according to the analysis with previous period return selection criteria. Portfolio 5 includes stocks with highest previous period returns. Portfolio 7 has more stocks with high returns. The results of the analysis reveal that portfolio 5 is also riskier than portfolio 7 . Therefore, investors can choose both portfolios depending on their risk profiles.

It is also interesting that portfolio selected with beta selection criterion is less risky and has less return than portfolio 5 portfolio investable according to previous return criterion. Therefore using beta selection criterion is a conservative alternative to previous return criterion.

\section{Conclusion}

There are various methods to compute optimal set of portfolios given stock returns in a market. This study suggests to include two selection criteria while using MVO technique. These criteria are beta (systematic risk) and previous period return.

Risk in finance is often analyzed in two broad categories. Systematic risk in the context of this study measure the sensitivity of stocks to market (exchange) movement. Non-systematic risk is diversifiable by adding assets to the portfolio. Because it is an idiosyncratic component based on company specific risks.

Previous period return is just the closing prices of stocks in the previous year of the research period. In finance, most analysis assume previous period returns correlate with the future prices. One can even forecast prices with previous period returns.

According to the results of this study, it is possible to include selection criteria and still obtain investable portfolios. For beta selection criteria, the portfolio with lowest beta values is optimal according to the result of this study.

Low beta stocks are also known as conservative stocks. The results of this study reveal that it is extremely beneficial to include these stocks to the portfolio. These stocks generate natural hedge benefits especially when the value of stocks in the market decrease.

Another aspect in this analysis is, increasing the number of stocks too much with low beta stocks doesn't generate better investment alternative. So according to this analysis, inclusion of lowest beta stocks even outweigh diversification benefits of adding stocks to the portfolio which is one of the fundamental techniques in portfolio theory.

The analysis with previous period returns also generate investable portfolios. It is possible to achieve higher return portfolio with previous period return criteria than beta selection criteria. This, of course come with higher risks. So, depending on investor profile both criteria may be used.

This analysis provide academic and practical benefits while suggesting these selection criteria in portfolio management. The standard practice doesn't always generate best portfolios due to high volatility financial markets which even violate normality assumption in Modern Portfolio Theory. The technique proposed in this research allow investor to decide the type of portfolio they want to hold based on beta and previous period return based expectations. This is a reflection of risk understanding and market expectations of the individual or corporate investor to portfolio selection which can not be maintained by standard practices. 
One of the modern techniques in portfolio management is the use of artificial intelligence and robo advisors. The technique allows to select and trade stocks and create portfolios based on inestors' risk profile. However, the technique offered in this research is superior since it allows to make choices in stock selection based on investor preference. Therefore portfolio management companies can integrate the criteria offered in this study to their algorithms.

From a social standpoint, the refelection of risk preferences in portfolios may generate better welfare for the investors. This would result an increase in the total savings and investments due to possible superior performance. Investment funds that operate portfolios in this basis can be created. Also government incentives in investments on these portfolios, may create a rapid increase of the portfolios. These portfolios may generate stable incomes depending on risk expectations determined by their investors.

The research proposes a new technique that can be integrated to Modern Portfolio Theory. The results reveal that the technique is applicable. However, the research is limited to sample data only. Therefore the research should be repeated in different time periods to check the validity in periods of financial turbulance and growth.

The future research in this field may focus on applying these techniques in other markets and time intervals. Cross country analysis may reveal the differences between emerging and developed markets. The proposed beta and previous period return selection criteria may also be applied with other stochastic methods instead of MVO in future applications.

\section{References}

Abu Bakar, N. (2019). Robust Statistical Portfolio Investment in Modern Portfolio Theory: A Case Study of Two Stocks Combination in Kuala Lumpur Stock Exchange. International Journal of Engineering and Advanced Technology, 8(5C). https://doi.org/10.35940/ijeat.E1031.0585C19

Atan, M. (2005). Portfolio Optimization with Quadratic Programming. VII. National Econometrics and Statistics Symposium.

Aygoren, H., \& Akyer, H. (2013). Data Interval in Determining Efficient Portfolios, Hisse Senedi Sayısı ve Risk Düzeyi Faktörlerinin Etkisi. Uluslararası Alanya İşletme Fakültesi Dergisi, 5(2).

Caliskan, T. (2011). Measurement of Portfolio Performance with Black-Litterman and Markowitz Mean Variance Optimization Models. Yönetim ve Ekonomi Araştırmaları Dergisi, 9(15).

Chen, J. C. (2000). Forecasting Method Applications to Recreation, and Tourism Demand. Doctoral Dissertation. USA: North Carolina State University.

Fischer, J. (2019). Modern Portfolio Theory and the Efficient Markets Hypothesis: How Well Did they Serve Canada's Baby-boom Generation? $12^{\text {th }}$ Economics and Finance Conference, Dubrovnik. https://doi.org/10.20472/EFC.2019.012.006

Kocadagli, O., \& Cinemre, N. (2010). Portfoy Optimizasyonunda SVFM ile Bulanık Dogrusal Olmayan Model Yaklasimi. Istanbul University Journal Of The School Of Business Administration, 39(2).

Linsmeier, T. J., \& Neil, D. P. (1996). Risk Measurement: An Introductin to Value at Risk. University of Urbana-Champaign, 1(24).

Lord, M. (2020). University Endowment Comitees, Modern Portfolio Theory and Performance. Journal of Risk and Financial Management, 13(198). https://doi.org/10.3390/jrfm13090198

Markowitz, H. (1952). Portfolio Selection. The journal of Finance, 7(1). https://doi.org/10.2307/2975974

Sharpe, W. F. (1988). Portfolio Theory and Capital Markets. McGraw Hill.

Ustaoglu, E., \& Altay, E. (2017). Application of Log-Optimal Portfolio in Istanbul Stock Exchange. Uygulamalı Sosyal Bilimler Dergisi, 1(1).

\section{Copyrights}

Copyright for this article is retained by the author(s), with first publication rights granted to the journal.

This is an open-access article distributed under the terms and conditions of the Creative Commons Attribution license which permits unrestricted use, distribution, and reproduction in any medium, provided the original work is properly cited. 